\title{
A simple model of foreign exchange exposure
}

\author{
Gordon M. Bodnar \\ The Paul H. Nitze School of Advanced International Studies \\ The Johns Hopkins University \\ 1740 Massachusetts Avenue NW \\ Washington, DC 20036 \\ 202-663-7731 \\ bodnar@jhu.edu \\ Richard C. Marston \\ Wharton School, University of Pennsylvania \\ 3620 Locust Walk \\ Philadelphia, PA 19104 \\ 215-898-7626 \\ marstonr@wharton.upenn.edu
}

October 30, 2000

\begin{abstract}
$\underline{\text { Abstract }}$
Foreign exchange exposure refers to the sensitivity of a firm's cash flows to changes in exchange rates. This study develops a model of foreign exchange exposure dependent on only three variables, the percentage of the firm's revenues and expenses denominated in foreign currency and its profit rate. Exposure is estimated for a sample of 103 U.S. firms that participated in the 1998 Wharton/CIBC Survey of Risk Management by U.S. Non-Financial Firms. The study finds that foreign exchange exposure is quite low for a majority of firms in the sample because these firms have been able to match their foreign currency revenues and costs leaving them with little net exposure. Such operational hedges may help to explain why previous studies have found low or negligible levels of exposure when they studied the sensitivity of share prices to foreign exchange rates.
\end{abstract}

Key word: foreign exchange exposure JEL classification: F3 
The foreign exchange rate exposure of a firm is a measure of the sensitivity of its cash flows to changes in exchange rates. Since cash flows are difficult to measure, most researchers have examined exposure by studying how the firm's market value, the present value of its expected cash flows, responds to changes in exchange rates. Empirical studies of the foreign exchange rate exposure of U.S. firms (for example, Jorion (1990), Bodnar and Gentry (1993), Amihud (1994), Choi and Prasard (1995), Griffin and Stulz (1997), and Allayannis (1997)), typically find low or negligible levels of exposure for most firms, even when the firms examined have significant foreign operations. This has been considered somewhat of a puzzle. None of these studies are based explicitly on a model of firm behavior, however, so it is difficult to interpret their findings of low exposure in terms of economic behavior. ${ }^{1}$

This paper develops a simple model of exposure that, when calibrated, provides estimates of exposure consistent with the previous findings of low exposure. The model is that of a monopoly firm whose revenues and expenses are exposed to changes in exchange rates. It demonstrates that exposures are related to net foreign currency revenues and profit margins, and that firms that develop operational hedges can shield themselves from the large scale effects of exchange rate changes. This paper calibrates the exposure of a group of U.S. firms that participated in the Wharton/CIBC 1998 Survey of Risk Management by U.S. Non-Financial Firms (Bodnar et al., 1998). Instead of using

\footnotetext{
${ }^{1}$ Bodnar, Dumas, and Marston (1999) provide an explicit theoretical model and they find relatively high levels of exposure. But their model is estimated for a group of Japanese firms that have been chosen because they are likely to have high levels of exposure, since their purpose is to investigate the link between pass-through and exposure behavior in firms that have high levels of exposure. Other theoretical studies of exposure include Adler and Dumas (1984), Hekman (1985), Shapiro (1975), Flood and Lessard (1986), von Ungern-Sternberg and von Weizsacker (1990), Levi (1994) and Marston (2001). None of these studies have attempted to provide empirical estimates of their models.
} 
a firm's share price behavior to measure exposure, the study uses measures of the firms' foreign currency revenues and costs from the Survey to develop direct estimates of their foreign exchange exposure. The estimates make use of an explicit model of exposure based on the profit-maximizing behavior of the firm.

\section{$\underline{\text { 1. Model Basics }}$}

To develop a measure of foreign exchange exposure, we need to start with an operational definition of a firm's value. The value of a firm can be expressed in terms of a stream of present and future cash flows as

$$
V=\sum_{t=1}^{\infty} \frac{C F_{t}}{(1+\rho)^{t}}
$$

where $C F_{t}$ represents the expected cash flows of the firm, which are equal to after-tax profits less net investment, and where $\rho$ is the discount rate. In order to keep the model tractable so that the effects of market structure can be examined, we assume that the net investment of the firm is equal to zero and that cash flows are expected to be constant from year to year. In that case, the present value can be written

$$
V=\frac{C F}{\rho}=\frac{(1-\tau)}{\rho} \pi
$$

where $\tau$ is the tax rate and $\pi$ is profit before taxes. The basic measure of foreign exchange exposure is $\mathrm{dV} / \mathrm{dS}$, where $\mathrm{S}$ is the exchange rate expressed as home currency/foreign currency. This measures the nominal value (in home currency) that is exposed to the exchange rate. With taxes and the discount rate constant, foreign exchange exposure becomes: 


$$
d V / d S=[(1-\tau) / \rho] d \pi / d S
$$

So foreign exchange exposure is proportional to the derivative of current profits with respect to the exchange rate. It is this latter derivative, $\mathrm{d} \pi / \mathrm{dS}$, that will be measured explicitly below.

\section{IA. Exchange rate exposure from a simple model}

To investigate foreign exchange exposure across a variety of firms, we must adopt a model of the firm that is versatile enough to take into account different forms of exposure. Exchange rates may affect a firm through a variety of channels:

(i) a firm may produce at home for export sales as well as domestic sales,

(ii) a firm may produce with imported as well as domestic components,

(iii) a firm may produce the same product or a different product at plants abroad.

The model of the firm must be broad enough to capture all of these channels.

The firm described below is a multinational firm (producing and selling at home and abroad) that uses both foreign and domestic components. Define the following variables:

$X, X^{*}=$ sales of the domestic good at home and abroad, respectively.

$Z, Z^{*}=$ sales of the foreign-produced good at home and abroad, respectively.

This good is produced by the domestic firm in a foreign plant.

$S=$ exchange rate (i.e., the dollar price of the Euro)

$C, C^{*}=$ cost functions, denominated in dollars and Euros, respectively, representing the cost of producing the domestic goods $\left(\mathrm{X}+\mathrm{X}^{*}\right)$.

$K, K^{*}=$ cost functions, denominated in dollars and Euros, respectively, representing the cost of producing the foreign goods $\left(Z+Z^{*}\right)$. 
The profit of the firm consists of net revenue earned on selling both domestic products and foreign products:

$$
\begin{aligned}
\Pi= & X D(X)+S X^{*} D^{*}\left(X^{*}\right)-C\left(X+X^{*}\right)-S C^{*}\left(X+X^{*}\right) \\
& +Z F(Z)+S Z^{*} F^{*}\left(Z^{*}\right)-K\left(Z+Z^{*}\right)-S K^{*}\left(Z+Z^{*}\right) .
\end{aligned}
$$

Because the firm is producing two products for two different markets, there are four firstorder conditions for this firm to be a profit maximizer.

$$
\begin{aligned}
& (d \Pi / d X)=D(X)+X D_{0}(X)-C_{0}\left(X+X^{*}\right)-S C_{0}{ }^{*}\left(X+X^{*}\right)=0 \\
& \left(d \Pi / d X^{*}\right)=S D^{*}\left(X^{*}\right)+S X^{*} D_{0}{ }^{*}\left(X^{*}\right)-C_{0}\left(X+X^{*}\right)-S C_{0}{ }^{*}\left(X+X^{*}\right)=0 \\
& (d \Pi / d Z)=F(Z)+Z F_{0}(Z)-K_{0}\left(Z+Z^{*}\right)-S K_{0}{ }^{*}\left(Z+Z^{*}\right)=0 \\
& \left(d \Pi / d Z^{*}\right)=S F^{*}\left(Z^{*}\right)+S Z^{*} F_{0}{ }^{*}\left(Z^{*}\right)-K_{0}\left(Z+Z^{*}\right)-S K_{0}{ }^{*}\left(Z+Z^{*}\right)=0
\end{aligned}
$$

In these expressions, the derivative of each function with respect to output is denoted by a subscript 0 .

The exchange rate exposure of the firm is obtained by differentiating the profit with respect to the exchange rate:

$$
\begin{aligned}
d \Pi / d S & =[d \Pi / d X](d X / d S)+\left[d \Pi / d X^{*}\right]\left(d X^{*} / d S\right)+[d \Pi / d Z](d Z / d S)+\left[d \Pi / d Z^{*}\right]\left(d Z^{*} / d S\right) \\
& +\left\{\left[X^{*} D^{*}\left(X^{*}\right)-C^{*}\left(X+X^{*}\right)\right]+\left[Z^{*} F^{*}\left(Z^{*}\right)-K^{*}\left(Z+Z^{*}\right)\right]\right\}
\end{aligned}
$$

According to this expression, there are two ways in which profits adjust to changes in the exchange rate. First, there can be output changes in response to the change in the exchange rate (these are the $\mathrm{dX} / \mathrm{dS}\left(\mathrm{dX}^{*} / \mathrm{dS}\right)$ and $\mathrm{dZ} / \mathrm{dS}(\mathrm{dZ} / \mathrm{dS})$ terms on the top line of (6)). Second, profits adjust in proportion to the initial level of net revenue denominated in foreign currency (this is the effect on the second line of (6)). 
However, this expression can be simplified by recognizing that from the first order condition given in (5), the response of profits to changes in output is equal to zero at the current equilibrium. This implies that if output is chosen optimally by the firm, only the direct effect of the exchange rate on profits remains. ${ }^{2}$ So the expression for exposure simplifies to:

\section{Exposure (derivative version):}

$$
d \Pi / d S=\left\{\left[X^{*} D^{*}\left(X^{*}\right)-C^{*}\left(X+X^{*}\right)\right]+\left[Z^{*} F^{*}\left(Z^{*}\right)-K^{*}\left(Z+Z^{*}\right)\right]\right\}
$$

The exchange rate exposure of the firm is equal to the initial level of net revenue denominated in foreign currency.

The empirical literature on exposure has typically measured the exposure elasticity (i.e., the percentage change in profits per percentage change in the exchange rate) rather than the nominal value exposure. The exposure elasticity, which we define as delta, is given by:

$$
\begin{aligned}
& \delta \quad=(d \ln \Pi / d \ln S)= \\
& =S\left\{\left[X^{*} D^{*}\left(X^{*}\right)-C^{*}\left(X+X^{*}\right)\right]+\left[Z^{*} F^{*}\left(Z^{*}\right)-K^{*}\left(Z+Z^{*}\right)\right]\right\} / \Pi
\end{aligned}
$$

This expression can be simplified if we define several new variables:

$$
\begin{aligned}
& R=\text { total revenue }=X D(X)+S X^{*} D^{*}\left(X^{*}\right)+Z F(Z)+S Z^{*} F^{*}\left(Z^{*}\right) . \\
& M=\text { total cost }=C\left(X+X^{*}\right)+S C^{*}\left(X+X^{*}\right)+K\left(Z+Z^{*}\right)+S K^{*}\left(Z+Z^{*}\right) . \\
& h_{1}=\text { foreign currency-denominated revenue as a percent of total revenue } \\
& \quad=S\left[X^{*} D^{*}\left(X^{*}\right)+Z^{*} F^{*}\left(Z^{*}\right)\right] / R
\end{aligned}
$$

\footnotetext{
${ }^{2}$ This result is discussed in detail in Marston (2001). As discussed in Marston, this result continues to hold under some but not all forms of oligopoly. For a more general discussion of the envelope theorem on which this analysis is based,
} 
$h_{2}=$ foreign currency-denominated costs as a percent of total costs

$$
=S\left[C^{*}\left(X+X^{*}\right)+K^{*}\left(Z+Z^{*}\right)\right] / M
$$

$r=$ the profit rate (i.e., profits as a percent of total revenues) $=\Pi / R$

We can then rewrite the expression for delta in terms of $h_{1}, h_{2}$, and $r$ :

\section{Exposure (delta version):}

$$
\begin{gathered}
\delta=h_{1}(R / \Pi)-h_{2}(M / \Pi)=\left(h_{1} / r\right)-h_{2}(1 / r-1) \\
\quad \text { or } \delta=h_{1}+\left(h_{1}-h_{2}\right)(1 / r-1)
\end{gathered}
$$

Delta is therefore a function of only three variables, $h_{1}, h_{2}$, and $r$.

\section{B. Exposures across types of firms}

Despite its simplicity, the expression for delta is general enough to encompass a variety of different firms. Consider the following examples of three different types of firms:

(1) U.S. exporter: This firm is assumed to produce all of its output at home and to sell a fraction, $\mathrm{h}_{1}$, abroad. All of the components needed for production, moreover, are produced at home (so $\mathrm{h}_{2}=0$ ). So its exchange rate exposure is given by

$$
\delta=\mathrm{h}_{1} / \mathrm{r} \quad \underline{\text { Pure exporter }}
$$

For example, if this firm sells one-half of its product abroad $\left(\mathrm{h}_{1}=0.5\right)$ and if its profit rate is $10 \%(\mathrm{r}=0.1)$, then delta is

$$
\delta=\mathrm{h}_{1} / \mathrm{r}=5.0
$$

A delta of 5.0 means that the firm's profits vary five times as much in percentage terms as the exchange rate. So a 10 percent depreciation of the domestic currency 
leads to a 50 percent rise in profits for the exporting firm. This is the type of firm that is explicitly modeled in Bodnar, Dumas, and Marston (1999).

(2) U.S. multinational: This firm is assumed to both produce and sell abroad. If this firm produces enough goods abroad to service foreign markets (so that $h_{1}=h_{2}$ ), then its foreign exchange delta takes a simple form:

$$
\delta=\mathrm{h}_{1} \quad \underline{\text { Multinational firm }}
$$

A firm that produces and sells half of its output abroad, for example, has a delta of 0.5. By producing abroad all of the products it sells in foreign markets, this firm has created a "operational hedge" for its foreign revenue exposure. Only its profits from foreign operations remain exposed.

(3) U.S. importer: This firm is assumed to sell nothing abroad $\left(\mathrm{h}_{1}=0\right)$, but needs to import its components. So its delta is given by

$$
\delta=\mathrm{h}_{2}(1 / \mathrm{r}-1) \quad \underline{\text { Pure importer }}
$$

For example, if the firm imports one-half of its components $\left(h_{2}=0.5\right)$ and if its profit rate is $10 \%$, then delta is

$$
\delta=\mathrm{h}_{2}(1 / \mathrm{r}-1)=-4.5 .
$$

Like the pure exporter, this firm has large foreign exchange exposure, but its exposure is opposite in sign to that of the exporter. For similar foreign activity and profit percentages, the exposure elasticity is smaller in magnitude than for the exporter because costs are not as large as revenues for a profitable firm.

These examples demonstrate that the exchange rate exposure of U.S. firms varies widely depending on the nature of their foreign activities. Exposure varies from the large positive net exposure of exporting firms to the large negative net exposure of importing 
firms. The multinational firm, on the other hand, has shielded itself from most of the exchange rate exposure due to its foreign sales by creating offsetting foreign currency costs through locating plants abroad.

Figure 1 shows how delta varies for different values of $h_{2}$ and $r$ for a given level of $h_{1}$. The firm is assumed to sell half of its output abroad, so $h_{1}=0.5$, while its foreign currency-denominated inputs vary between zero and $100 \%$ (so $\mathrm{h}_{2}$ varies between 0 and 1.0). Two curves are drawn for profit rates, $r$, of $10 \%$ and $20 \%$. It is evident from the figure that the delta swings from large positive values to large negative values as the proportion of foreign costs $\left(\mathrm{h}_{2}\right)$ increases (i.e., as the firm changes from being a net exporter to a net importer). A positive exposure of 0.5 is found for the firm that has $\mathrm{h}_{2}=$ $\mathrm{h}_{1}=0.5$ (case 2 above). Equally interesting is the impact of higher profitability on exposure. As the rate of profit ( $\mathrm{r}$ ) rises from $10 \%$ to $20 \%$, the exposure of the firm is substantially reduced, particularly for firms with large positive or negative exposures. For a pure exporter, for example, exposure falls from 5.0 to 2.5 as profit rises from $10 \%$ to $20 \%$.

\section{Estimates of foreign exchange exposure}

The natural question to ask is where U.S. firms fit in this range of possibilities. To answer that question, we need information about three sets of variables, revenues and costs denominated in foreign currency and profits. Two of these variables can be estimated (although imperfectly) based on accounting data provided in annual reports.

(a) Any U.S. firm with $10 \%$ or more of its revenues from foreign countries must provide a "geographical segment" table in its annual report that separates foreign from U.S. 
revenues. The model above calls for revenues denominated in foreign currency which may be different from foreign revenues since U.S. firms often price some products destined for foreign markets in U.S. dollars. So the accounting data that is available provides only an imperfect estimate of $h_{1}$.

(b) U.S. firms also report profits and total revenues, so an estimate of $r$ can also be obtained.

(c) The third variable in the expressions for delta is $h_{2}$, the proportion of costs that is denominated in foreign currency. There is no accounting data on foreign currencydenominated costs. Nor, as far as we know, are there other estimates of $h_{2}$ available in published sources.

So despite the fact that delta depends on only three variables, it is not possible to obtain an estimate of delta using published data.

A survey of derivative use by U.S. non-financial firms that was conducted by the Wharton School and CIBC Wood Gundy in $1998^{3}$ does provide data on $h_{1}$ and $h_{2}$ that can be used to derive estimates of $\delta$. This survey was completed by 399 non-financial firms based in the United States. Of these 399 firms, 176 reported using foreign exchange derivatives. We choose to study the latter set of firms since presumably they are more likely to have foreign exchange exposure. The survey included two questions that are relevant to the present analysis:

(i) What percentage of your consolidated operating revenues are in foreign currency?

(ii)What percentage of your consolidated operating costs are in foreign currency?

\footnotetext{
${ }^{3}$ Bodnar et al. (1998).
} 
The answers to these questions provide direct estimates of the $h_{l}$ and $h_{2}$ variables in the expressions above. 138 of the 176 firms using foreign exchange derivatives responded to these two questions.

We obtain estimates of $r$ from accounting data in the annual reports of the firms involved. Some of the 138 firms have merged with other firms or have been acquired by other firms, so these firms are omitted from the sample. Of the remaining firms, we included all those firms whose annual reports are readily available on the web and who reported positive income in $1998 .^{4}$ Our sample consists of 103 firms.

Figure 2 sorts the 103 firms by their foreign exchange exposure elasticity (delta). At the left of the figure are those firms with large positive exposure because their foreign currency revenues exceed their foreign currency costs. These export-oriented firms experience a large increase in profits when the dollar depreciates. At the other extreme on the right of the figure are the net importers whose foreign currency costs exceed their foreign currency revenues. Consider two representative firms with large positive and negative exposures, respectively. ${ }^{5}$ The first firm is a pharmaceutical firm with a delta of 1.6. For this firm, $40 \%$ of its sales are in foreign currency, while only $15 \%$ of its costs are in foreign currency. Even with a profit rate above $15 \%$, it has a relatively high exposure to foreign exchange rates. (Note that if its profit rate were only $5 \%$, its exposure would rise to 5.1, so its exposure is very sensitive to the profit rate). The second firm is an equipment manufacturer with $40 \%$ of its costs in foreign currency, but

\footnotetext{
${ }^{4}$ Since delta measures the log change in profits, we confine the sample to firms that have positive profits. 120 firms had annual reports available on the web. Of these, 17 had negative (or zero) income, leaving us with our sample of 103 firms.

${ }^{5}$ The firms participating in the survey were guaranteed confidentiality, so we will not be able to identify the names of the firms being studied. There is no need to identify specific firms since our purpose
} 
with only $30 \%$ of its revenue in foreign currency. With a relatively low profit rate of 2.7 $\%$, it has a large negative delta of -3.3 . But firms like these with high absolute exposure are the exception rather than the rule. Only 29 firms or $28 \%$ of the firms in the sample have positive exposures greater than one, and only 17 firms have negative exposures (indicating that their foreign currency expenditures are relatively large).

For most of the firms in the sample, the deltas are between zero and one, so their foreign exchange exposure is limited. In most cases, this is because the firm's net revenue exposure (revenue - cost denominated in foreign currency) is close or equal to zero. As explained earlier, a firm with zero net revenue exposure has a delta equal to the fraction of foreign currency revenues to total revenues, so its delta must be between zero and one. ${ }^{6}$ Many of those firms have developed operational hedges by producing much of what they sell abroad in plants located abroad. One typical example is that of a consumer products firm that produces and sells products both at home and abroad. This firm reported that $50 \%$ of both its revenues and its costs were denominated in foreign currency. So its delta is 0.50 regardless of its rate of profit. ${ }^{7}$

How typical are such cases of multinational firms that shield themselves from most foreign currency exposure through operational hedges? Based on the sample of 103 firms in the survey, the answer seems to be that such multinational firms are the rule rather than the exception. 57 firms of the 103 firms examined in this study have deltas between zero and one. Many of the firms in the sample, in fact, have deltas between

\footnotetext{
is to demonstrate that exchange rate exposure elasticities are low, specifically, below one, for a large percentage of U.S. firms.

${ }^{6}$ That is, if $h_{1}=h_{2}$, the delta is equal to $h_{1}$ which is a fraction less than one. It should be noted that if the firm operated in some types of oligopolistic industries, however, then the delta could be larger or smaller than $\mathrm{h}_{1}$ even when the firm has balanced revenues and expenses. See Marston (2001).
} 
zero and 0.25 . The 29 firms in this category have (a) balanced revenues and expenses in foreign currency, and (b) revenues (and expenses) in foreign currency that are $25 \%$ or less of total revenues (expenses).

Based on these findings, it is not surprising that past empirical studies examining the response of share prices to exchange rates have found relatively little evidence of exposure. Even firms that derive more than half of their revenue from abroad may have a delta less than one if their expenses in foreign currency match their revenue.

\section{Conclusion}

This paper develops a simple model of foreign exchange exposure to explain why previous studies have found such low exposure in most U.S. and foreign firms. The model is that of a firm that both produces and sells at home and abroad. The expression for foreign exchange exposure that is derived is simple enough so that exposure can be estimated without using the share price data that has been used in previous empirical studies of exposure. Not all of the data required for estimating exposure is available from published sources, so we have drawn on the results of a survey of U.S. firms.

For many firms in the study, foreign exchange exposure is quite low because these firms have been able to match their foreign currency revenues and costs quite effectively. Operational hedging, by which we mean the shifting of production and sourcing abroad to match revenues in foreign currency, has succeeded in reducing exposure to modest levels. The only firms to contend with larger foreign exchange exposure are those with unbalanced revenue or cost streams. For those firms, sizable financial hedges may be necessary to moderate their exposure.

\footnotetext{
${ }^{7}$ The model assumes that the profit rate for foreign operations is the same as for domestic operations.
} 


\section{REFERENCES}

Adler, Michael, and Bernard Dumas, 1984. "Exposure to Currency Risk: Definition and Measurement," Financial Management, Summer, 41-50.

Allayannis, George, 1997. "The Time-Variation of the Exchange-Rate Exposure: An Industry Analysis," Darden School Working Paper, University of Virginia DSWP \# 9729, December.

Amihud, Yakov, 1994, "Exchange Rates and the Valuation of Equity Shares," in Yakov Amihud and Richard Levich, editors, Exchange Rates and Corporate Performance, New York: Irwin, 49-59.

Bodnar, Gordon M., Bernard Dumas, and Richard C. Marston, 1999, "Pass-through and Exposure," Weiss Center for International Finance Working Paper 98-1, February (revised version, August 1999).

Bodnar, Gordon M., and William M. Gentry, 1993. "Exchange Rate Exposure and Industry Characteristics: Evidence from Canada, Japan, and the USA," Journal of International Money and Finance, February, 29-45.

Bodnar, Gordon M., Richard C. Marston and Greg Hayt, 1998, 1998 Survey of Financial Risk Management by U.S. Non-Financial Firms, Wharton School, July.

Choi, J.J., and A. Prasad, 1995, "Exchange Risk Sensitivity and Its Determinants: A Firm and Industry Analysis of U.S. Multinationals," 24(3), Financial Management.

Flood, Eugene Jr., and Donald R. Lessard, 1986. "On the Measurement of Operating Exposure to Exchange Rates: A Conceptual Approach," Financial Management, Spring, 25-37.

Griffin, J.M., and R. Stulz, 1997, "International Competition and Exchange Rate Shocks: Cross-Country Industry Analysis of Stock Returns," Dice Center W.P. 98-7 OSU.

Hekman, Christine, 1985. “A Financial Model of Foreign Exchange Exposure," Journal of International Business Studies, Summer, 83-99.

Jorion, Phillippe, 1990. "The Exchange-Rate Exposure of U.S. Multinationals," Journal of Business, July, 331-345.

Levi, Maurice D., 1994. "Exchange Rates and the Valuation of Firms," in Yakov Amihud and Richard M. Levich, editors, Exchange Rates and Corporate Performance. New York: Irwin, 37-48. 
Marston, Richard C., 2001, "The Effects of Industry Structure on Economic Exposure," Journal of International Money and Finance, April 2001, forthcoming.

Shapiro, Alan C., 1975, "Exchange Rate Changes, Inflation, and the Value of the Multinational Corporation," Journal of Finance, May, 485-502.

von Ungern-Sternberg, Thomas, and C.C. von Weizsacker, 1990, "Strategic Foreign Exchange Management," Journal of Industrial Economics, June, 381-395.

Varian, Hal R., Microeconomic Analysis, Norton, 3rd edition, 1992. 
Figure 1. Delta (for $h_{1}=0.5$ )

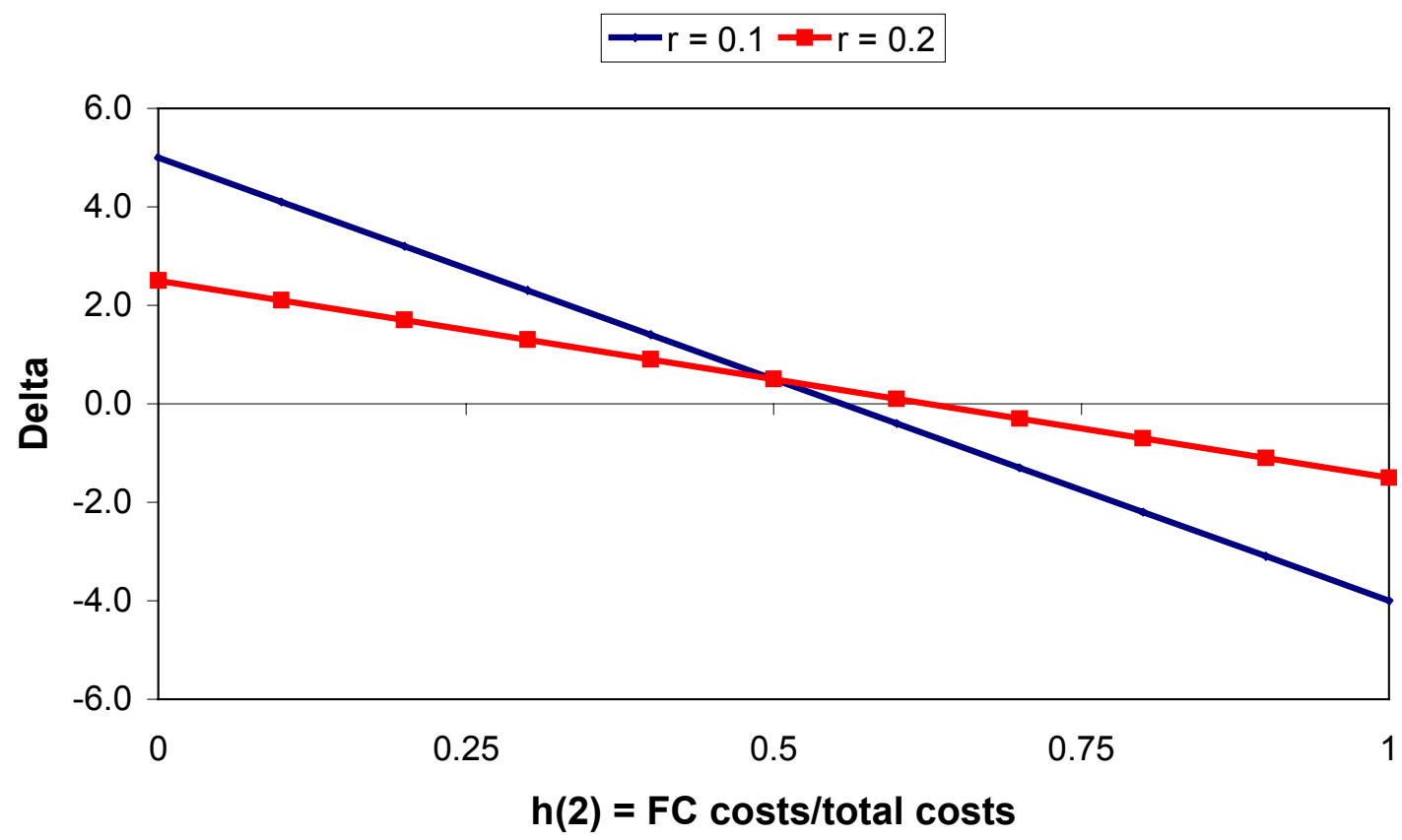

Figure 2. Calculated Deltas for 103 Firms

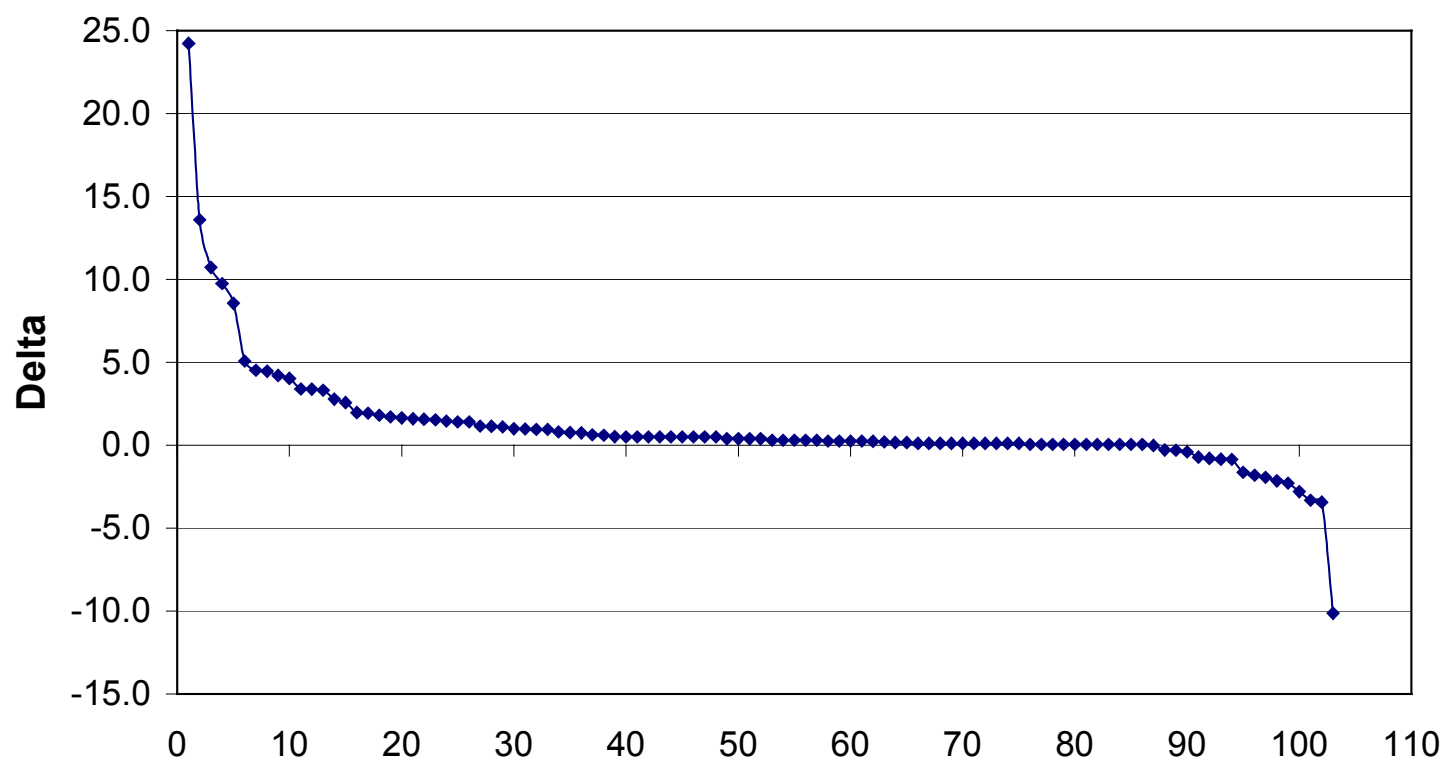

Firms in Sample 